\title{
Moans, groans and renal stones: an interesting case of abdominal pain
}

\author{
Christopher Myles Rowe, ${ }^{1}$ Maneesh Ghei, ${ }^{2}$ Ewelina Adamska ${ }^{3}$
}

${ }^{1}$ Intensive Care Unit, The

Whittington Hospital, London, UK

${ }^{2}$ Department of Urology and Urolodynamics, The

Whittington Hospital, London, UK

${ }^{3}$ Department of Microbiology, The Whittington Hospital, London, UK

Correspondence to Dr Christopher Myles Rowe, christopher.m.rowe@doctors. net uk

\section{DESCRIPTION}

A 71-year-old man attended A\&E reporting swelling in his left flank, which increased during the 6 weeks prior to admission. Concomitantly, he had experienced persistent fevers and $13 \mathrm{~kg}$ weight loss. His medical history included a myocardial infarction and 4 months prior to admission, a transurethral resection of the prostate. The patient denied being diabetic and any history of recent travel.

Abdominal examination revealed a $5 \mathrm{~cm} \times 5 \mathrm{~cm}$ painful, fluctuant subcutaneous mass. The left kidney was not palpable. Interestingly, the pain was exacerbated by left hip flexion. Cardiovascular examination revealed the patient to be warm peripherally, tachycardic and to have a flash capillary refill. All other examinations were normal.

On admission, blood tests demonstrated a white cell count of $20.0 \times 10^{9} / \mathrm{L}$ and $\mathrm{C}$ reactive protein of $155 \mathrm{mg} / \mathrm{L}$. The patient was anaemic (haemoglobin $10.5 \mathrm{~g} / \mathrm{dL}$ ). Renal function was normal. Urine dip was negative, with microscopy, culture and sensitivity revealing moderate white cell numbers but no significant growth. He proceeded to an ultrasound of the abdomen and subsequent CT of the abdomen/ pelvis, which identified a complex of loculated collections originating from the mid pole of the left kidney (figure 1) to the left psoas muscle (figure 2a) and to the left flank subcutaneous tissues (figure 2b).

A percutaneous drain was placed, from which puss drained; culture and sensitivities grew Proteus mirabilis.

The differential diagnosis included chronic pyelonephritis and xanthogranulamatous pyelonephritis

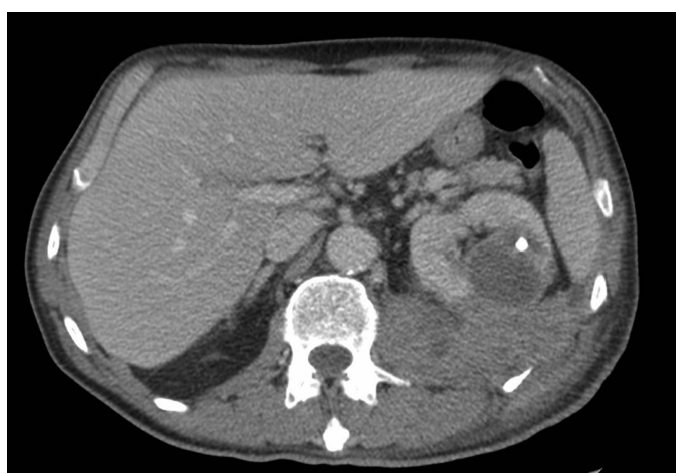

Figure 1 Axial CT demonstrates a $6 \mathrm{~mm}$ renal calculi, and renal and posterior perinephric abscess, illustrated by the absence of a clearly defined posterior kidney edge.
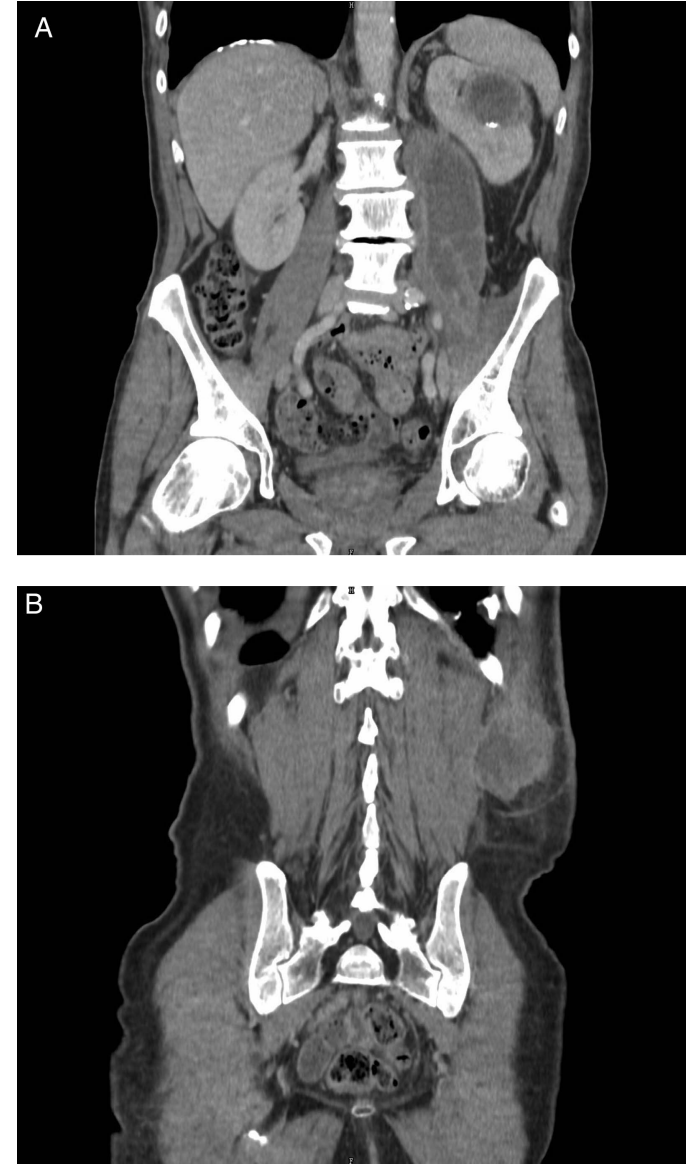

Figure 2 (A, B) The coronal CT images (and axial image in figure 1) demonstrate loculated collections: the renal component measured

$3.8 \mathrm{~cm} \times 3.6 \mathrm{~cm} \times 4.6 \mathrm{~cm}$, the psoas component

$17 \mathrm{~cm} \times 6 \mathrm{~cm} \times 4.6 \mathrm{~cm}$ and the subcutaneous component $4.1 \mathrm{~cm} \times 5.8 \mathrm{~cm} \times 6.6 \mathrm{~cm}$. Two renal calculi were identified: a $7 \mathrm{~mm}$ stone in the epicentre of the renal collection and a $6 \mathrm{~mm}$ calculus in the posterior calix of the renal upper pole (figure 1).

(XNP). The latter is a rare inflammatory disorder characterised by diffuse renal destruction as the parenchyma is replaced by lipid-laden macrophages. ${ }^{1} 2$ XNP commonly presents in middle age, being strongly associated with $P$ mirabilis and renal stones. ${ }^{1-3}$ Antibiotics and drainage lead to better mortality outcomes. ${ }^{2}$

Although on this admission XPN was not conclusively diagnosed, the patient was worked up for ureteroscopy, potential percutaneous extraction of the renal calculi or nephrectomy.
To cite: Rowe $C M$, Ghei $M$ Adamska E. BMJ Case Rep Published online: [please include Day Month Year] doi:10.1136/bcr-2013202035 


\section{Learning points}

- It is important to acquire a detailed history and clinical examination; the chronic history of symptoms not only identifies complications of commonly presenting conditions, for example, urinary tract infections and chronic pyrlonephritis, but also enables recognition of conditions (eg, xanthogranulamatous pyelonephritis (XPN)) which mimic other pathologies.

- XPN has no specific ultrasonographic features; however, parenchymal thinning, hydronephrosis, chronic obstructive uropathy due to calculi, and perinephric collections are suggestive.

- In XPN, CT demonstrates renomegaly \pm calculus and multiple non-enhancing areas due to dilated calyxes and abscess cavities, which enhance in chronic pyelonephritis and tumours.
Acknowledgements The authors would like to thank the Whittington Hospital radiology department for their assistance in providing the most suitable images.

Contributors All the authors were involved in the drafting of the article and in revising it critically for important intellectual content.

Competing interests None.

Patient consent Obtained.

Provenance and peer review Not commissioned; externally peer reviewed.

\section{REFERENCES}

1 Brown PS Jr, Dodson M, Weintrub PS. Xanthogranulomatous pyelonephritis: report of nonsurgical management of a case and review of the literature. Clin Infect Dis 1996:22:308-14.

2 Afgan F, Mumtaz S, Ather Hammad M. Preoperative diagnosis of xanthogranulomatous pyelonephritis. Urol J 2007:4:169-73.

3 Li L, Parwani A. Xanthogranulomatous pyelonephritis. Arch Pathol Lab Med 2011;135:671-4.

Copyright 2013 BMJ Publishing Group. All rights reserved. For permission to reuse any of this content visit http://group.bmj.com/group/rights-licensing/permissions.

BMJ Case Report Fellows may re-use this article for personal use and teaching without any further permission.

Become a Fellow of BMJ Case Reports today and you can:

- Submit as many cases as you like

- Enjoy fast sympathetic peer review and rapid publication of accepted articles

- Access all the published articles

- Re-use any of the published material for personal use and teaching without further permission

For information on Institutional Fellowships contact consortiasales@bmjgroup.com

Visit casereports.bmj.com for more articles like this and to become a Fellow 